\title{
MAKNA BECAMPU' DALAM ADAT PERNIKAHAN MASYARAKAT BINTUHAN KABUPATEN KAUR
}

\author{
'Ismi Nurhasanah; ${ }^{2}$ Sarwit Sarwono; ${ }^{3}$ Agus Joko Purwadi \\ ${ }^{1,2,3}$ Program Studi Pendidikan Bahasa Indonesia FKIP Universitas Bengkulu
}

Abstrak

\section{Korespondensi: Isminur_hasanah@yahoo.com}

Tujuan penelitian ini adalah untuk mendeskripsikan proses dan makna pengantin becampu' dalam adat pernikahan masyarakat Bintuhan. Analisis mengenai tradisi pengantin becampu' dilakukan dengan mengikuti prinsip-prinsip dalam kajian etnografi, yaitu dengan menekankan pada penafsiran tentang fenomena kebudayaan dalam masyarakat tertentu. Hasil penelitian tersebut sebagai berikut: tradisi pengantin becampu' adalah tradisi untuk mempersatukan pengantin laki-laki dan perempuan setelah ijab kabul. Tradisi ini dilaksanakan pada sore hari setelah ijab kabul dengan tiga rangkaian proses, yaitu (1) penyambutan, (2) membuka kain penghalang pintu, (3) membuka kain penutup wajah pengantin perempuan. Pelaksanaan tradisi pengantin becampu' didahului dengan seni pertunjukan be'eduk yang menampilkan enam tari adat, yaitu tari saputangan, tari mabuk, tari adau-adau, tari piring, tari pincak, dan tari selendang. Makna becampu' bagi masyarakat Bintuhan selain sebagai proses untuk menyatakan bahwa pengantin laki-laki dan perempuan sah bersanding, juga sebagai peneguh interaksi sosial antar masyarakat, sehingga becampu' dapat dikatakan sebagai sebuah tradisi yang tidak bisa ditinggalkan dalam adat pernikahan dalam masyarakat Bintuhan.

Kata Kunci: pengantin becampu', bintuhan, etnografi

\section{Abstract}

The purpose of this study was to describe the process and meaning of pengantin becampu' in the wedding customs of the Bintuhan community. Analysis of the pengantin becampu' tradition of tradition is done by following the principles in ethnographic studies, namely by emphasizing the interpretation of cultural phenomena in certain societies. The results of the study are as follows: the tradition of pengantin becampu' is a tradition to unite the bride and groom after being granted obedience. This tradition is carried out in the afternoons after being granted obedience with three sets of processes, namely (1) welcoming, (2) opening the door barrier fabric, (3) opening the cloth covering the bride's face. The implementation of the pengantin becampu' tradition is preceded by the performing arts of Beed, which features six traditional dances, namely saputangan dance, mabuk dance, adau-adau dance, piring dance, pincak dance, and selendang dance. The becampu' meaning for the Bintuhan community is not only as a process of stating that brides and grooms are equal, also as reinforcement of social interaction between communities, so that becampu 'can be said as a tradition that cannot be abandoned in traditional customs in Bintuhan communities.

Keywords: Pengantin Becampu', Bintuhan, Ethnography 


\section{PENDAHULUAN}

Penduduk asli Kaur, seperti yang dituturkan oleh H. Nawawi, terhimpun dalam tiga adat, dan setiap adat terpecah ke dalam beberapa marga. Pertama, Adat Pasemah yaitu marga Padang Guci yang sekarang tersebar kedalam enam kecamatan. Kedua, Adat Semende yaitu terdiri dari marga Muara Sawung, Ulak Bandung, Sungai Aru, Ulu Danau, Ulu Nasal, dan Suku Tiga Muara Nasal. Ketiga, Adat Kaur merupakan adat terbesar di Kabupaten Kaur yang terdiri dari marga Muara Sambat, Bandar Bintuhan, Tetap, Luas, Ulu Luas, Semidang Gumay, dan Muara Kinal.

Bintuhan merupakan Ibu Kota Kabupaten Kaur yang terhimpun dalam satu Kecamatan, yaitu Kecamatan Kaur Selatan. Kehidupan masyarakat Bintuhan masih terbilang tradisional. Hal ini ditandai dengan masih banyak tradisi leluhur yang dilestarikan, khususnya adalah tradisi pada acara pernikahan. Pernikahan di masyarakat Bintuhan dilaksanakan dengan berbagai rangkaian kegiatan sesuai dengan adat yang berlaku. Malam hari menjelang hari pernikahan (ijab qabul) diadakan Bedendang yaitu kesenian yang akan mengiringi calon pengantin selama tradisi beinai, dalam adat Kaur disebut pengantin bepaca'. Pada siang harinya dilaksanakan ijab kabul atau pengucapan ikrar pernikahan yang diiringi dengan tradisi maulid atau berzikir. Setelah ijab qabul berlangsung, maka menurut kepercayaan masyarakat Bintuhan pengantin laki-laki dan pengantin perempuan belum bisa dipertemukan, dalam adat Kaur disebut becampu'. Untuk mempertemukan kedua pengantin, di masyarakat Bintuhan dilaksanakan proses pengantin becampu' yang dalam pelaksanaannya diawali dengan bela'ak petang yang dilanjutkan dengan menampilkan seni pertunjukan be'eduk.

Pengantin becampu' adalah bagian kecil dari adat pernikahan masyarakat Bintuhan yang tidak bisa ditinggalkan, karena tradisi ini merupakan proses untuk mempertemukan pengantin laki-laki dengan pengantin perempuan setelah melaksanakan ijab kabul. Secara sederhana, pengantin becampu' dapat dikatakan sebagai proses yang harus dilalui oleh pengantin laki-laki untuk bisa bersanding dengan pengantin perempuan setelah pernikahan. Pengantin becampu' dilaksanakan dengan tiga tahapan, pertama pengantin lakilaki akan disambut oleh orang tua pengantin perempuan dengan air pengapian yang dipercikkan menggunakan daun setetu' dari kepala hingga ke kaki pengantin laki-laki, kedua ketika sampai di pintu, pengantin laki-laki dan pendampingnya (penggapit) akan kembali dihalangi dengan kain oleh Ketua Kerja perempuan dengan kain panjang yang melintang pintu, ketiga, ritual terakhir untuk membuka kain penutup wajah pengantin perempuan, sedangkan Be'eduk merupakan seni pertunjukan yang dilaksanakan sebelum proses pengantin becampu' dengan menampilkan enam jenis tari adat yang disertai lantunan pantunpantun dengan iringan tabuhan gendang. Tari yang dipertunjukkan pada pertunjukan be'eduk adalah tari saputangan, mabuk, adau-adau, piring, pincak, dan selendang, sedangkan pantun-pantun dalam pertunjukan be'eduk berupa pantun nasihat, agama, nasib, kasih sayang, harapan, dukacita, kias, dan pantun budi pekerti.

Kekayaan tradisi dan budaya dalam masyarakat Bintuhan seperti tradisi pengantin becampu' dan pertunjukan seni be'eduk dapat dikatakan sebagai folklor, karena folklor merupakan ekspresi dari masyarakat berbudaya. Yadnya (dalam Endraswara, 2009:28) menjelaskan bahwa folklor dapat mencakup semua pengetahuan, tingkah laku, asumsi, perasaan, dan kepercayaan yang tersebar dalam bentuk tradisional melalui praktik-praktik kebiasaan. Tradisi pengantin becampu' jika ditinjau dari segi folklor, dapat digolongkan ke 
dalam folklor sebagian lisan, karena tradisi ini memiliki komponen yang perlu diketahui yaitu pelaku, proses berlangsungnya tradisi pengantin becampu', waktu, situasi yang terbentuk pada saat berlangsungnya tradisi tersebut, dan alat-alat musik daerah yang digunakan. Hal ini sejalan dengan pendapat seorang ahli folklor dari Amerika Serikat, Jan Harold Brunvand (dalam Danandjaja, 1994:21-22), yang mengemukakan bahwa folklore sebagian lisan (partly verbal folklore) adalah folklor yang sebagian bentuknya merupakan campuran unsur lisan dan bukan lisan. Bentuk-bentuk folklor yang yang termasuk kelompok besar selain kepercayaan rakyat adalah permainan rakyat, tarian rakyat, adat istiadat, upacara, pesta rakyat dan lain-lain.

Upaya pelestarian tradisi pengantin becampu' dan seni pertunjukan be'eduk pada masyarakat Bintuhan sebenarnya sudah dilakukan oleh pemangku adat dan beberapa penggiat kesenian yang ada di Kaur, khususnya masyarakat Bintuhan, namun upaya tersebut masih tergeser dengan selera masyarakat yang kebarat-baratan selalu ingin mempersingkat waktu pelaksanaan pernikahan, sehingga seringkali tradisi pengantin becampu' dianggap sebagai hal yang membuang-buang waktu dan biaya. Tradisi pengantin becampu' merupakan budaya warisan leluhur yang mengandung makna dan nilai-nilai budaya yang layak untuk disampaikan pada acara pernikahan, karena secara tidak langsung akan dapat memberikan pengaruh terhadap perjalanan kehidupan untuk kedua pengantin, sehingga seharunya tradisi ini dipertahankan oleh masyarakat Bintuhan itu sendiri.

Berdasarkan keadaan tersebut, maka peneliti tertarik untuk meneliti mengenai becampu' dalam adat pernikahan masyarakat Bintuhan yang dilihat dari aspek maknanya. Penelitian ini penting karena dengan adanya penelitian ini diharapkan dapat menghimbau kepada masyarakat luas supaya dapat menjaga dan melestarikan tradisi-tradisi yang diajarkan di daerah masing-masing. Penelitian ini juga akan memberikan pengetahuan tentang proses dan makna pengantin becampu' dalam adat pernikahan masyarakat Bintuhan Kabupaten Kaur. Oleh karena itu, untuk mengetahui tentang tradisi pengantin becampu pada masyarakat Bintuhan, dalam penelitian ini peneliti mengangkat permasalahan tentang proses dan makna becampu' dalam adat pernikahan masyarakat Bintuhan Kabupaten Kaur.

\section{METODE}

Metode penelitian yang digunakan dalam penelitian ini adalah metode penelitian kualitatif etnografi. Etnografi digunakan untuk meneliti perilaku-perilaku manusia berkaitan dengan perkembangan teknologi komunikasi dalam setting sosial dan budaya tertentu. Metode penelitian etnografi dianggap mampu menggali informasi secara mendalam dengan sumber-sumber yang luas. Secara sederhana, etnografi dapat dikatakan sebagai upaya untuk memperhatikan makna-makna tindakan dari kejadian yang menimpa orang atau sekelompok orang yang ingin kita ketahui. Beberapa makna tersebut terekspresikan secara langsung dalam bahasa, dan di antara makna yang diterima, banyak yang disampaikan hanya secara tidak langsung melalui kata-kata dan perbuatan.

Penelitian ini dilakukan di Desa Jembatan Dua, dan Desa Gedung Sako Kecamatan Kaur Selatan Kabupaten Kaur. Penelitian ini dilaksanakan pada bulan Februari 2019 dengan cara mengamati proses tradisi pengantin becampu' yang ditampilkan dan mewawancarai informan yang memahami betul mengenai tradisi pengantin becampu' dalam adat pernikahan di Kecamatan Kaur Selatan. Data dalam penelitian ini adalah 
berupa hasil dari pengamatan langsung pada lingkungan penelitian, dari hasil dokumentasi, dan wawancara secara mendalam kepada informan mengenai proses pengantin becampu' yang dilaksanakan dalam adat pernikahan di Kecamatan Kaur Selatan. Sumber data dalam penelitian ini adalah dokumentasi berupa video, foto, wawancara informan, dan pengamatan langsung.

Analisis data dalam penelitian ini dilakukan dengan mengikuti prinsip-prinsip dalam etnografi, yaitu dengan mengamati langsung proses suatu kebudayaan, mendengarkan percakapan yang terjadi ketika proses budaya tersebut dilaksanakan, membaca dokumen yang dihasilkan dari lapangan, lalu mengajukan pertanyaan, namun yang paling membedakan etnografi dengan metode lainnya adalah peran yang lebih aktif ditugaskan pada gaya kognitif untuk melihat, mengamati, dan meneliti.

\section{HASIL DAN PEMBAHASAN}

Masyarakat Bintuhan adalah masyarakat yang dalam keseharian tidak bisa terlepas dari adat. Adat menjadi pengatur segala tingkah laku. Mulai dari kelahiran, pernikahan, sampai dengan kematian, masing-masing diatur dengan ketentuan adat yang berbeda. Pernikahan di masyarakat Bintuhan adalah kegiatan yang paling kental dengan adat istiadat. Setiap proses yang terjadi harus sesuai dengan adat yang berlaku. Pernikahan pada masyarakat Bintuhan dimulai dengan kegiatan berasan atau ngantat tanci, lalu dilanjutkan dengan mufakat atau pekat adik sanak yang dilaknasakan dua malam sebelum ijab kabul, lalu malam bepaca' yang dilaksanakan malam sebelum ijab kabul. Keesokan harinya dilaksanakan ijab kabul.

Setelah ijab kabul, dalam adat Bintuhan pengantin laki-laki dan perempuan belum boleh bertatap muka secara langsung ditandai dengan belum dibukanya kain penutup muka pengantin perempuan. Untuk mempertemukan pengantin laki-laki dan perempuan, dalam adat Kaur dilaksanakan proses pengantin becampu' atau pengantin bersanding. Proses pengantin becampu' pada masyarakat Bintuhan dilaksanakan sore hari pukul 16.00-18.00 WIB, diawali dengan pengantin laki-laki diarak dari rumah tumpak menuju tempat pengantin perempuan. setelah tiba di tempat pengantin perempuan, pengantin laki-laki dan rombongan akan dipersilahkan menyaksikan pertunjukan be'eduk.

\section{Be'eduk}

Be'eduk dalam bahasa Bintuhan diartikan sebagai proses ketika seseorang melantunkan pantun dengan nada-nada tertentu. Seni pertunjukan ini memadukan antara unsur musik, tari dan pantun. Musik yang diciptakan adalah dari sebuah alat musik gendang yang ditabuh oleh satu atau dua orang sambil melantunkan pantun dengan nadanada tertentu. Tari akan diperankan oleh 2-4 orang secara berpasangan dengan mengenakan pakaian berupa jas hitam, celana pancang, kain sebatas lutut, dan peci hitam. Tari yang ada pada pertunjukan be'eduk bermacam-macam, yaitu tari saputangan, tari mabuk, tari adau-adau, tari piring, tari pincak, dan tari selendang. Tari tersebut akan dipertunjukkan secara berurutan. Masing-masing tari memiliki 'eduk yang berbeda dengan pantun yang berbeda pula.

Dalam be'eduk terdapat 'eduk, yaitu berupa pantun-pantun yang dilantunkan dengan nada tertentu sesuai dengan tari yang diperankan. Misalnya dalam tari mabuk, maka yang dilantunkan adalah 'eduk tari mabuk. Ketika yang dipertunjukkan adalah tari adau-adau, maka 'eduk yang dilantunkan akan berbeda dengan tari sebelumnya. Pantun 
yang dilantunkankan biasanya berisi tentang kehidupan, agama, ajakan, nasihat, sindiran, dan pantun budi.

Dari mana hendak kemana

Dari Jepun ke Bandar Cina

Kami bina numpang bertanya

Bunga setangkai siapa punya

Pantun di atas merupakan pantun kasih sayang atau cinta yang disampaikan oleh tukang 'eduk untuk menggelitik perasaan pengantin laki-laki. Kata "kami pada pantun di atas tertuju kepada para pelaku pertunjukkan, yaitu tukang 'eduk dan para penari. Sedangkan, kata "bunga" pada pantun di atas tertuju kepada pengantin perempuan yang sudah dipersunting oleh pengantin laki-laki. Biasanya ketika mendengar pantun ini, pengantin laki-laki akan tersenyum karena merasa bahwa pantun tersebut ditujukan kepadanya.

\section{Anake arab turun ke arab \\ Tiba di Arab membeli kain \\ Kalau Tuan dapat dibarap \\ Tidak kami cari yang lain}

Pantun di atas merupakan pantun harapan yang memiliki makna bahwa dalam sebuah pernikahan, antara laki-laki dan perempuan yang akan menikah harus memiliki ketulusan dan sikap bersungguh-sungguh. Pantun ini menyatakan bahwa hakikat sebuah pernikahan adalah sakral dan tidak bisa didasari dengan sikap berpura-pura. Kata "tuan" pada pantun di atas tertuju kepada pihak laki-laki, dan kata "kami" pada pantun di atas tertuju kepada pihak perempuan yang menuntut keseriusan pihak laki-laki ketika akan mempersunting seorang perempuan.

Laut baik kuale dalam

Langit cincin je'igi ki'i

Bu'uk baik mintak digenggam

Ndai bidup sampai ke mati

Pantun di atas merupakan jenis pantun harapan. Makna dari pantun ini adalah ketika seseorang sudah menyerahkan hidupnya kepada orang lain, maka ia mengharapkan semua baik dan buruk dalam dirinya dapat diterima dengan ikhlas. Pantun ini disampaikan pada acara pernikahan berarti bahwa, ketika seorang wanita sudah menerima pinangan dari seorang laki-laki, maka laki-laki tersebut harus menerima kekurangan dan kelebihan wanita tersebut dengan sepenuh hati dan akan terus menjaganya hingga akhir kehidupan.

Anaknye elang anak lenlayang

Pandai menyimba' si bunge baru

Laut nye liba' bekace ka'ang

Manekan pacak sampan lalu

Pantun di atas merupakan jenis pantun nasib yang memiliki makna bahwa kehidupan terkadang membawa kita ke dalam sebuah situasi yang menyulitkan yang dapat membuat kita putus harapan. Tetapi dalam pantun tersebut juga memberikan gambaran bahwa harapan itu masih ada jika kita selaku manusia biasa dapat menghadapi situasi yang sulit tersebut dengan fikiran yang positif dan optimis. Jenis pantun seperti ini disampaikan dalam situasi pernikahan diharapkan dapat membuka fikiran pasangan yang baru mengarungi rumah tangga tentang kehidupan yang tidak selamanya selalu indah, dan 


\section{Ismi Nurhasanah; Sarwit Sarwono; Agus Joko Purwadi}

diharapkan pasangan yang baru ini siap menghadapi segala situasi dalam kehidupan berkeluarga.

\section{Kelaut numbakekan lidi}

Pecah kembiling ditumpaskan

Dalamnye laut gelumbang api

Adik sayang dilepaskan

Pantun di atas termasuk ke dalam jenis pantun kias yang memiliki makna bahwa ada hal yang tidak dapat dilawan oleh sepasang kekasih, yaitu restu dari orang tua. Ketika restu tersebut tidak didapat maka pilihan yang harus diambil adalah melepaskan. Bait "dalamnye laut gelumbang api" pada pantun ini berarti keadaan yang dianggap tenang ternyata mampu menimbulkan masalah yang teramat besar. Ketika pantun ini disampaikan pada konteks pernikahan, maka makna pantun ini mengarah kepada pasangan yang akan membangun rumah tangga harus memiliki restu dari kedua orang tua, agar tidak terjadi masalah yang berkepanjangan nantinya dalam kehidupan berkeluarga.

Be'eduk menjadi penting dalam proses pengantin becampu', karena dalam pertunjukan be'eduk terdapat pula tari-tarian dan pantun-pantun yang memiliki makna tersendiri. Tari dalam be'eduk merupakan tari adat yang memiliki gerakan dasar bela diri yang dianggap sebagai gambaran kehidupan pada masyarakat Bintuhan dahulu yang mempercayai adanya guru tua berupa harimau hitam yang menjadi panutan dalam belajar ilmu bela diri. Keadaan alam yang masih dikelilingi dengan hutan liar, memaksa masyarakat untuk membekali diri mereka dengan kemampuan bela diri yang mumpuni. Fungsi dan kegunaan tari dalam suatu sistem budaya sebenarnya bervariasi, seperti yang diungkapkan oleh Sedyawati (1981:71) bahwa ada sistem budaya yang menganggap tari sebagai fungsi sentral, ada pula sistem budaya yang menganggap tari tidak begitu penting. Sedang kegunaan tari dalam suatu sistem budaya dapat bervariasi pula, ia bisa mempunyai kegunaan sebagai sarana silaturahmi, sarana pendidikan, sarana peneguhan kepercayaan keagamaan, sebagai pembinaan fisik dan sebagainya.

Pantun-pantun yang dilantunkan dalam be'eduk secara keseluruhan mencerminkan kehidupan sehari-hari masyarakat Bintuhan, mulai dari kehidupan beragama, bersosial, dan ekonomi. Pantun pada be'eduk juga memiliki makna kasih sayang atau cinta, sesuai dengan kondisi saat pantun tersebut disampaikan, yaitu pada saat pernikahan. Teks pantun pada be'eduk tidak memiliki pedoman pokok yang mencakup jenis dan lainnya, hal ini bersifat bebas sesuai dengan kemampuan dan kreatifitas tukang 'eduk dalam berpantun. Pantun-pantun tersebut akan mengalami perubahan bunyi sesuai dengan kebutuhan pada saat pertunjukan berlangsung. Sejalan dengan itu, diungkapkan oleh Amir (2013:117) bahwa penggubahan teks dipengaruhi oleh irama dendang, juga oleh khalayak dalam bentuk permintaan. Seni pertunjukan membawa dampak perubahan kepada teks, yaitu terjadinya penambahan bunyi-bunyi pengimbuh.

\section{Proses Becampu'}

Proses ritual pengantin becampu' dimulai pada saat pengantin laki-laki hendak melangkahkan kaki pertama kali ke rumah pengantin perempuan. Ada tiga proses yang harus dilewati pengantin laki-laki dalam ritual pengantin bencampu' ini. Pertama, ketika posisi pengantin laki-laki berada di tangga rumah, pengantin laki-laki akan disambut oleh ibu pengantin perempuan. Penyambutan ini dilakukan dengan memercikkan air putih dengan 
menggunakan daun setetu'(daun yang berbentuk gerigi), dan mengarahkan asap tempurung kelapa yang ditaburi dengan beras kepada pengantin laki-laki. Air putih dipercikkan ke pengantin laki-laki mulai dari ujung kepala hingga ujung kaki, lalu asap tempurung akan di arahkan ke wajah pengantin laki-laki. Proses ini memiliki makna bahwa ketika pengantin laki-laki dan pengantin perempuan sudah berada dalam satu rumah maka diharapkan akan dapat menjalani kehidupan yang baik, baik dari segi sandang yang disimbolkan dengan air yang dipercikkan, baik dari segi pangan yang disimbolkan dengan beras yang dibakar, baik dari segi papan yang disimbolkan dengan langkah kaki pengantin laki-laki ketika akan memasuki rumah pengantin perempuan.

Kedua, pengantin laki-laki akan diberhentikan ketika sudah sampai di depan pintu rumah pengantin perempuan. Setelah selesai pada proses yang pertama, pengantin lakilaki dan pendampingnya (penggapit) melangkah menuju pintu rumah. Pintu rumah tersebut sudah dihalangi dengan kain oleh Ketua Kerja perempuan. Pada proses ini yang harus membuka kain penghalang pintu tersebut adalah pendamping (penggapit) pengantin lakilaki. Pendamping pengantin laki-laki harus bisa mengambil hati Ketua Kerja yang berperan sebagai penjaga pintu tersebut, yaitu pertama-tama merayu untuk meminta penghalang pintu dibuka tanpa syarat. Jika hal ini tidak berhasil, maka pendamping pengantin laki-laki harus memberikan uang dengan jumlah yang sesuai dengan keinginan Ketua Kerja sebagai penawar. Jika Ketua Kerja merasa uang yang diberikan oleh pendamping (penggapit) pengantin laki-laki sudah cukup, maka penghalang pintu akan dibuka dan pengantin laki-laki dapat melanjutkan ke proses yang terakhir.

Ketiga, proses terakhir yang harus dilewati oleh pengantin laki-laki adalah membuka penutup wajah pengantin perempuan. Pengantin perempuan yang masih dalam posisi wajah tertutup, akan dijaga oleh pendamping (penggapit) pengantin perempuan. Pada proses ini pengantin laki-laki sudah diperbolehkan untuk duduk di sebelah pengantin perempuan. Sementara, pendamping (penggapit) pengantin laki-laki akan merayu pendamping (penggapit) pengantin perempuan untuk meminta membuka penutup wajah pengantin perempuan. Rayuan pertama dilakukan hanya dengan kata-kata tanpa memberikan penawar. Biasanya pendamping pengantin perempuan tidak akan membuka penutup wajah pengantin perempuan dengan begitu mudahnya, sehingga pendamping pengantin laki-laki akan memberikan penawar berupa uang kepada pendamping pengantin perempuan.

Pertimbangan dalam hal menyatakan bahwa uang yang diberikan itu cukup atau tidaknya, biasanya berdasarkan jumlah biaya untuk membeli seperangkat alat perhiasan untuk pengantin perempuan. Dalam hal ini, pendamping pengantin perempuan (penggapit) tidak diperbolehkan untuk mempersulit proses ritual ini berlangsung, artinya sebelum proses ini dilaksanakan, antara pendamping pengantin laki-laki dan pendamping pengantin perempuan sudah diberi arahan dan sudah dipersiapkan segala sesuatunya dengan baik, misalnya dari tata cara memulai pembicaraan, tata cara membalas pembicaraan, sampai pada jumlah uang yang ada di dalam amplop tersebut sedah dipersiapkan secara baik dan lengkap. Jika pendamping (penggapit) pengantin perempuan merasa uang yang diberikan sudah cukup, maka penutup wajah pengantin perempuan akan dibuka. Proses membuka penutup wajah pengantin perempuan akan diiringi dengan sorak sorai masyarakat yang menyakasikan sebagai tanda masyarakat juga merasakan kebahagiaan kedua pasangan yang sudah sah untuk bersanding. 
Proses kedua dan ketiga merupakan proses yang mencerminkan satu makna, yaitu menggambarkan bahwa pernikahan bukan suatu hal yang dapat diangap sebagai permainan. Hal ini disimbolkan dengan harus adanya uang yang diberikan agar pengantin laki-laki dapat bersanding dengan pengantin perempuannya. Proses kedua dan ketiga ini tidak dilakukan oleh pengantin laki-laki, melainkan hanya dilakukan oleh pendamping (penggapit) pengantin laki-laki, dan pengantin laki-laki hanya menyaksikan berada di sebelah penggapit. Proses ini memberikan gambaran kepada pengantin laki-laki bahwa setiap hal dalam pernikahan haruslah diusahakan dengan sebaik-baiknya, terlebih sebagai kepala keluarga.

Setelah pembuka wajah pengantin perempuan dibuka, maka rombongan yang menjadi pengiring pengantin dan rombongan pertunjukan be'eduk dipersilahkan untuk menikmati hidangan dari tuan rumah. Selanjutnya, pihak panitia acara akan membagikan bunga yang ada di jambar nasi kuning dibagikan kepada penonton sebagai tanda terima kasih telah ikut serta memeriahkan acara pernikahan. Setelah semua rangkaian acara selesai, maka Ketua Kerja laki-laki segera menutup acara secara resmi.

\section{Makna}

Makna becampu' dalam adat pernikahan masyarakat Bintuhan dibentuk dengan adanya pantun, tari, proses yang berlangsung, dan suasana yang terbentuk ketika tradisi tersebut dilaksanakan. Pantun dalam tradisi becampu' yang dilantunkan pada saat pertunjukan be'eduk secara keseluruhan memiliki makna pengharapan akan sebuah perjalanan hidup yang baru bagi kedua pasangan pengantin. Sedangkan, tari dalam tradisi becampu' yang pertunjukkan saat pertunjukan be'eduk memiliki makna sebagai perwujudan dari keadaan kehidupan masyarakat Bintuhan pada zaman sebelum modern yang belum terdapat alternatif dalam melakukan aktivitas sehari-hari, sehingga mengharuskan masyarakat khususnya kaum laki-laki untuk memiliki kemampuan untuk mempertahankan diri dari serangan baik itu manusia atau serangan dari hewan buas, artinya tari adat pada pertunjukan be'eduk menggambarkan kemampuan seseorang dalam mempertahankan diri dengan gerakan yang indah yang merupakan perpaduan antara seni tari dan bela diri.

Secara keseluruhan, unsur-unsur tersebut membentuk sebuah sistem tingkah laku sosial masyarakat Bintuhan yang secara resmi menggambarkan adat istiadat dan norma yang berlaku dalam masyarakat tersebut. Sejalan dengan ini Koentjaraningrat (1994:7), menyatakan bahwa kebudayaan juga sering disebut sebagai sistem sosial mengenai kelakuan berpola manusia itu sendiri, yang terdiri dari aktivitas-aktivitas manusia yang berinteraksi, berhubungan, serta bergaul satu dengan yang lainnya.

\section{PENUTUP}

Berdasarkan pendahuluan dan pembahasan hasil penelitian yang telah peneliti uraikan tentang pengantin becampu' dalam adat pernikahan masyarakat Bintuhan Kecamatan Kaur Selatan Kabupaten Kaur Provinsi Bengkulu, peneliti dapat menyimpulkan bahwa, pengantin becampu' adalah tradisi yang terdapat dalam adat pernikahan masyarakat Bintuhan untuk mempersatukan pengantin laki-laki dan pengantin perempuan setelah ijab kabul dengan tiga tahapan, yaitu penyambutan ketika pengantin laki-laki akan memasuki rumah pengantin perempuan, membuka penghalang pintu, dan membuka kain penutup wajah pengantin perempuan. Tradisi ini didahului oleh pertunjukan seni be'eduk yang 
menampilkan tari-tari adat dengan lantunan pantun daerah, yang secara keseluruhan dapat dimaknai sebagai cerminan kehidupan sehari-hari masyarakat Bintuhan, mulai dari kehidupan beragama, bersosial, dan ekonomi.

Berdasarkan kesimpulan di atas terdapat beberapa saran yang dapat di sampaikan yaitu sebagai berikut:

1. Setelah peneliti melakukan penelitian di lapangan mengenai tradisi pengantin becampu', khusus pada bagian seni pertunjukan, peneliti melihat bahwa terdapat perbedaan be'eduk antara penggiat yang satu dengan penggiat yang lainnya. Perbedaan tersebut terlihat mulai dari 'eduk, urutan pertunjukan, hingga gerakan tari. Mengenai hal ini, peneliti mengemukakan saran kepada peneliti berikutmya agar dapat meneliti tentang perbedaan yang terdapat dalam be'eduk di Kabupaten Kaur.

2. Penelitian ini akan menjadi arsip kedaerahan, khususnya bidang kebudayaan Kabupaten Kaur dalam bentuk buku proses tradisi pengantin becampu'. Mengenai hal ini, peneliti sangat menyarankan agar ada pihak yang berkenan untuk membukukan proses pengantin becampu' seperti yang telah peneliti uraikan sesuai dengan syarat dan ketentuan yang berlaku.

\section{DAFTAR PUSTAKA}

Amir, Adriyetti. 2013. Sastra Lisan Indonesia. Yogyakarta: CV ANDI OFFSET.

Danandjaja, James. 1994. Folklor Indonesia Ilmu Gosip, Dongeng, dan lain-lain: PT.Utama Grafiti.

Endraswara, Suwardi. 2009. Metodologi Penelitian Folklor. Yogyakarta: MedPress.

Koentjaraningrat. 1994. Kebudayaan Mentalitas dan Pembangunan. Jakarta: Gramedia Pustaka Utama

Sedyawati, Edi. 1981. Pertumbuhan Seni Pertunjukan. Jakarta: Sinar Harapan. 